\title{
PENGARUH VARIASI SUDUT UJUNG MATA POTONG KARBIDA TERHADAP KEKASARAN DAN TOPOGRAFI PERMUKAAN LOGAM Al 6061 PADA PROSES PEMBUBUTAN
}

\author{
Sobron Lubis, Rosehan dan Rico Wiguna \\ Program Studi Teknik Mesin Fakultas Teknik Universitas Tarumanagara \\ Jl.Letjend.S.Parman No.1 Jakarta 11400 \\ e-mail: sobronl@ft.untar.ac.id
}

\begin{abstract}
In the process of metal cutting, cutting tools is an important factor to consider. Selection of cutting parameters and cutting tools geometry contributes to the surface condition of the resulting workpiece, especially surface roughness. The nose radius of cutting tools is a piece that rubs against the workpiece that will form a scratch to produce a flake. Various types of cutting tools angles today are developed and certainly give effect to changes in surface roughness of the workpiece and topography. To know the condition of surface workpiece produced, then conducted research influence variation tool nose radius cutting tools to roughness and topography surface workpiece. This research was conducted using CNC lathe. Three variations of end of carbide insert tip used i.e. 0.4, 0.8, and $1.2 \mathrm{~mm}$ are installed. Right on tool holder cutting tools. The cutting speed used is $500 \mathrm{~m} / \mathrm{min}$, depth of cut $0.2 \mathrm{~mm}$, and feeding of $0.3 \mathrm{~mm}$ / put. Material workpiece aluminum alloy type 6061 turning without using coolant. The workpiece of the lathe result is measurement of surface roughness by using Mitutoyo surface test, and observation of workpiece surface condition done by Jenco digital microscope model BC 4-311. The result of the analysis shows that the surface roughness value is inversely proportional to the increase of nose radius cutting tools tool. The larger the nose radius cutting tools, the smaller the surface roughness. The lowest roughness value is $1.046 \mu \mathrm{m}$ with cutting speed of $500 \mathrm{~m} / \mathrm{min}$ and $1.2 \mathrm{~mm}$ tool nose radius cutting tools. The percentage decrease in surface roughness with the difference of nose radius cutting tools tool is $12.24 \%$.
\end{abstract}

Keywords: Surface roughness, topography, cutting speed, aluminum alloy.

\section{PENDAHULUAN}

Proses permesinan logam tidak dapat dipisahkan dari penggunaan mata pahat potong. Sifatsifat dan geometri mata pahat potong memberi spesifikasi tersendiri terhadap parameter pemotongan yang hendak digunakan. Sedangkan pada pemilihan parameter pemotongan pada proses pemesinan yang akan memberi efek terhadap perubahan kondisi permukaan benda kerja, umur pahat, waktu pemesinan, gaya dan daya pemotongan. Mata pahat potong memiliki sudut ujung mata pahat (tool nose radius) secara langsung bersentuhan dengan permukaan benda kerja yang menimbulkan hasil goresan tersebut. Goresan tersebut membentuk kontur permukaan yang tidak rata dan dikenal dengan kekasaran permukaan (surface roughness).

Mesin bubut CNC (Computer Numerically Control) merupakan salah satu dari mesin perkakas modern, memiliki dasar mekanisme operasional yang sama dengan mesin bubut konvensional. Perbedaanya adalah mesin bubut konvensional masih menggunakan operator, sehingga kualitas dari benda kerja yang diproduksi sangat berpengaruh terhadap operator. Semakin handal operator mengoperasikan mesin, maka semakin bagus benda kerja yang dihasilkan. Sedangkan pada mesin bubut CNC, operator hanya mengawasi mesin yang beroperasi dan tidak berpengaruh sama sekali terhadap kualitas produk, karena proses permesinan dilakukan oleh komputer. Pada mesin bubut CNC, operator dapat membuat hasil dari benda kerja menjadi sangat optimal karena semua parameter dalam mesin CNC dapat terukur dan dapat dibuat konstan. Kalpakjian \& Schmid mengatakan bahwa parameter yang sangat menentukan kekasaran permukaan adalah kedalaman pemakanan (depth of cut), laju pemakanan (feed rate) dan kecepatan potong[6]. Demikian pula Rochim mengatakan bahwa hasil komponen proses pembubutan terutama permukaan sangat dipengaruhi oleh sudut potong pahat, kecepatan makan (feeding), kecepatan potong (cutting speed), kedalaman pemotongan (depth of cut) dan lain-lain[1].

Kekasaran permukaan (surface roughness) merupakan ketidakteraturan konfigurasi suatu permukaan ditinjau dari profilnya. Maksudnya dari konfigurasi adalah batasan yang memisahkan 
benda pada sekelilingnya[4]. Salah satu karateristik geometris yang ideal dari suatu komponen adalah permukaan yang halus.

Salah satu contoh parameter yang dapat diubah-ubah dan dapat berjalan secara konstan adalah cutting speed. Cutting speed adalah kecepatan mata pahat melakukan proses pemakanan benda kerja dalam jarak per waktu terhadap permukaan benda kerja. Sedangkan faktor lain yang dapat divariasikan dari segi mata pahat adalah tool nose radius. Tool nose radius merupakan radius ujung mata pahat yang bersentuhan langsung dengan benda kerja. Berdasarkan parameter permesinan di atas, dengan menggunakan mesin CNC dilakukan proses pemesinan logam yang bertujuan untuk melakukan analisa pengaruh cutting speed dan tool nose radius terhadap kondisi permukaan dan topografi permukaan benda kerja yang dihasilkan.

\section{METODE PENELITIAN}

Penelitian ini dilakukan dengan metode eksperimental. Sebanyak 15 sampel benda kerja yang digunakan pada proses pembubutan. Diagram alir prosedur eksperimen disampaikan pada Gambar 1.

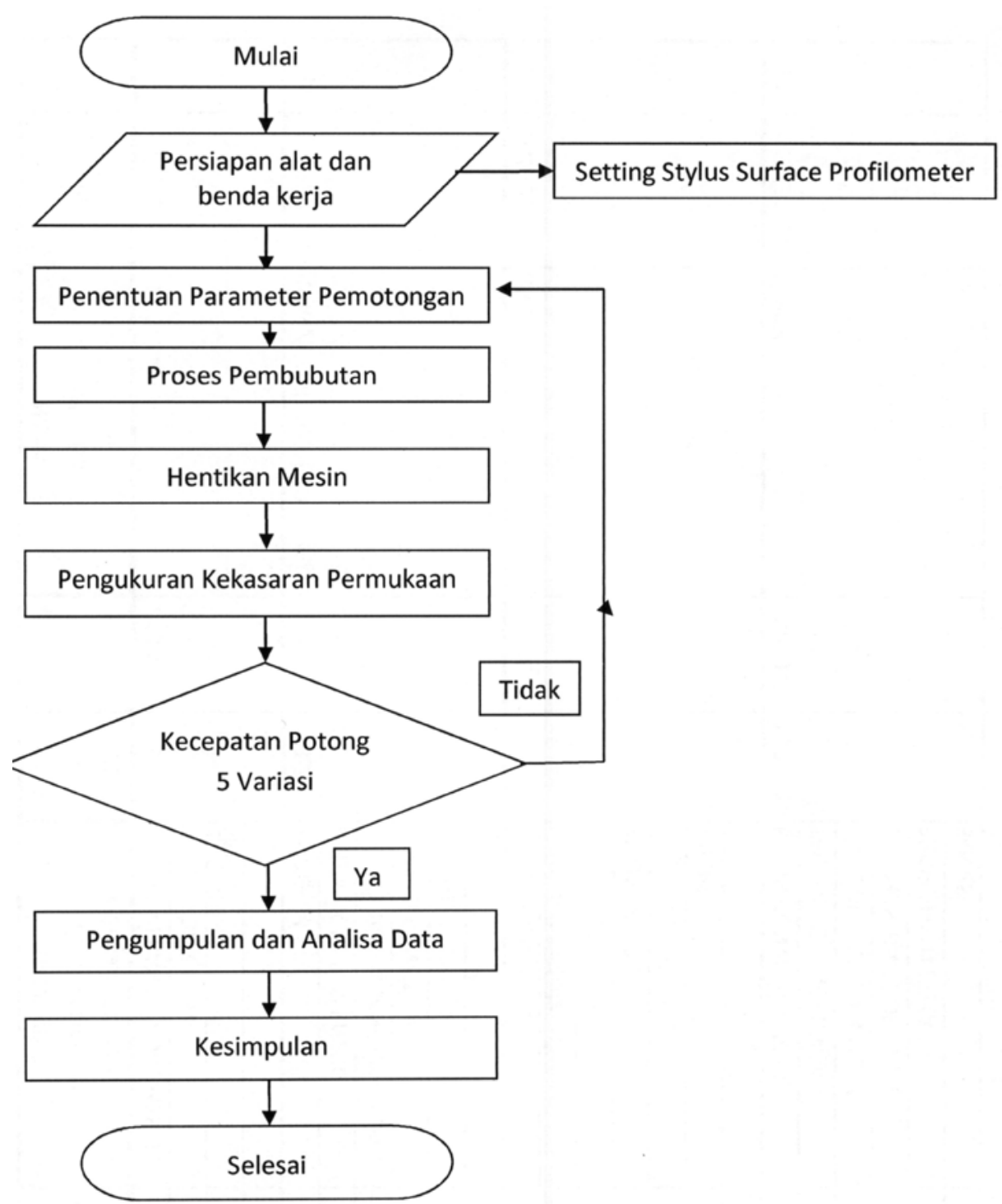

Gambar 1. Diagram alir prosedur eksperimen

\section{Peralatan dan Bahan:}

Adapun peralatan dan bahan yang digunakan pada eksperimen ini antara lain: 
- Mesin CNC Mazak Quick Turn 8n

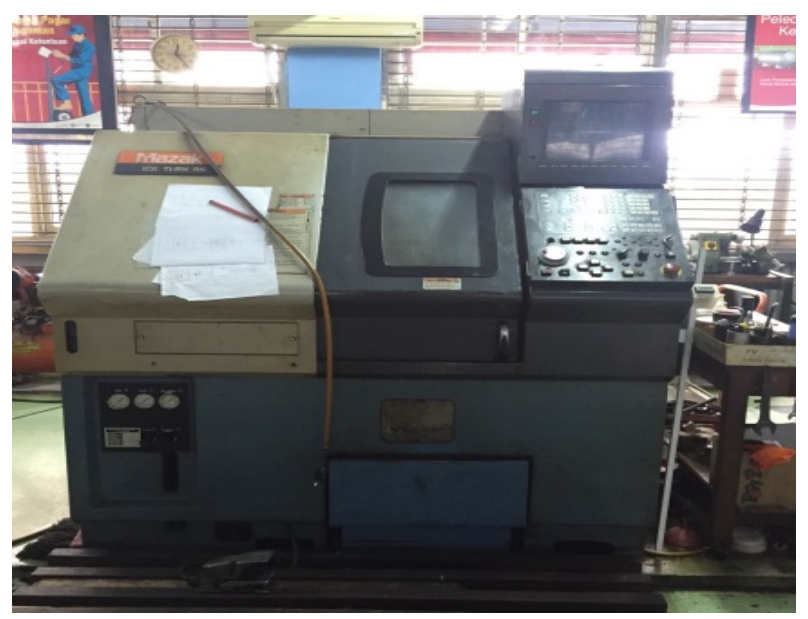

Gambar 2. Mesin bubut

- Mikroskop Digital

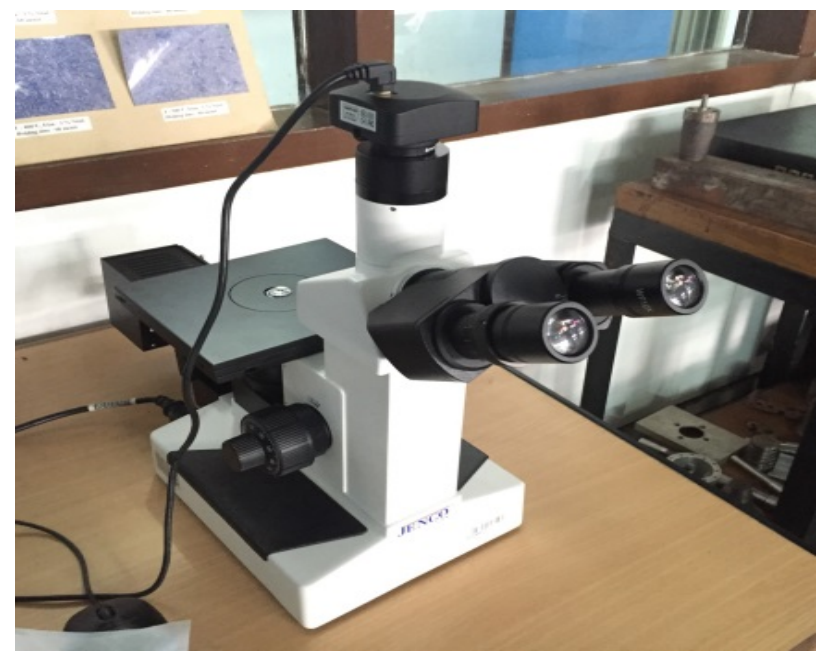

Gambar 3. Mikroskop digital Jenco BC4-311

- $\quad$ Surftest Mitutoyo 211

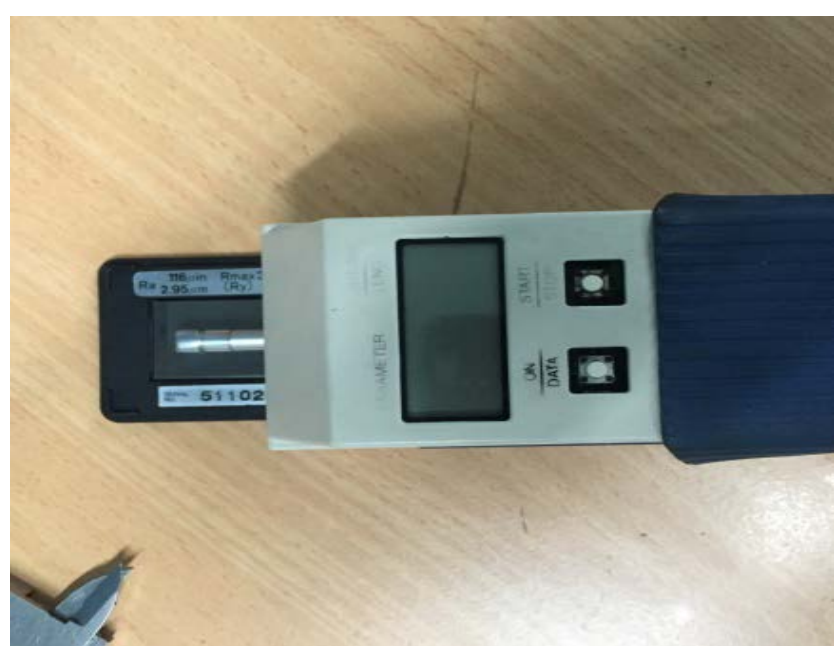

Gambar 4. Mitutoyo surftest 211 
- Bahan Benda Kerja

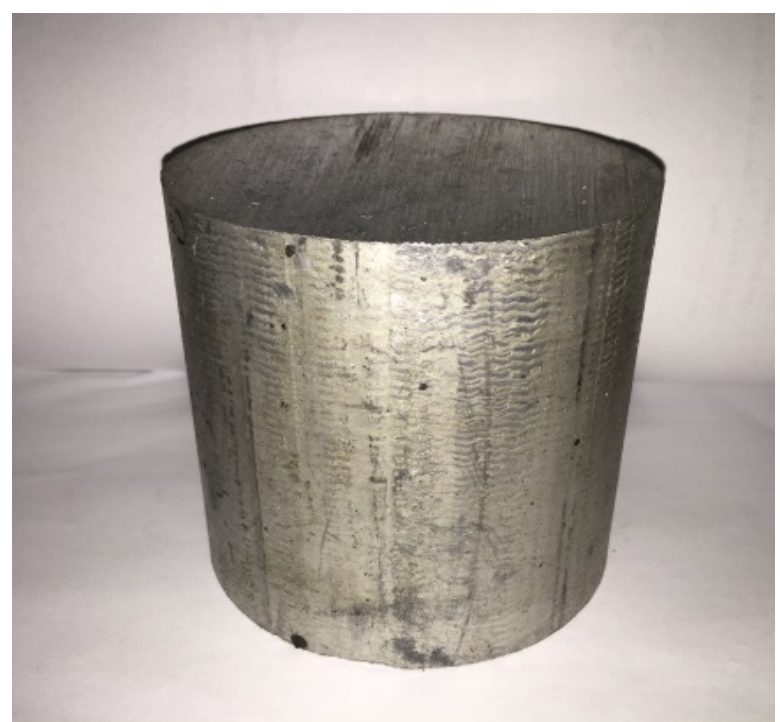

Gambar 5. Bahan aluminum 6061

- Mata Pahat (TNMG160404, TNMG160408, TNMG160412)

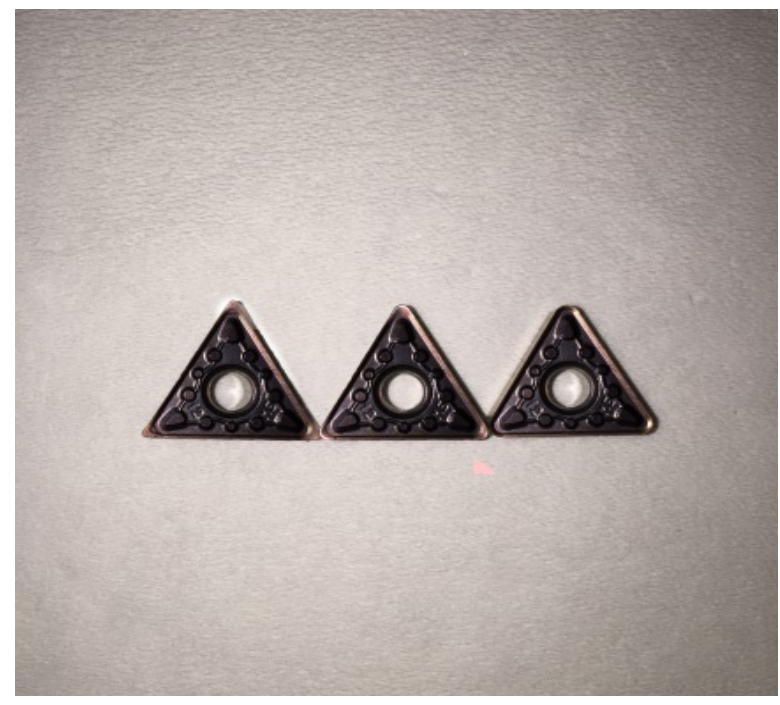

Gambar 6. Mata pahat karbida

\section{HASIL DAN PEMBAHASAN}

Hasil pengukuran kekasaran permukaan dapat dilihat pada Tabel 1. Pada tabel tersebut dapat dilihat angka kekasaran permukaan yang paling kecil adalah 1,046 $\mu \mathrm{m}$ sedangkan yang paling besar $2,23 \mu m$.

Tabel 1. Rata-rata nilai kekasaran permukaan benda kerja

\begin{tabular}{|c|c|c|c|c|c|}
\hline \multirow{3}{*}{$\begin{array}{l}\text { TNR } \\
(\mathrm{mm})\end{array}$} & \multicolumn{5}{|c|}{ Kecepatan Potong (m/min) } \\
\hline & 200 & 300 & 400 & 500 & 600 \\
\hline & \multicolumn{5}{|c|}{ Surface Roughness ( $\mu \mathrm{m})$} \\
\hline 0,4 & 2,23 & 1,909 & 1,48 & 1,368 & 1,43 \\
\hline 0,8 & 1,602 & 1,524 & 1,334 & 1,098 & 1,21 \\
\hline 1,2 & 1,216 & 1,14 & 1,078 & 1,046 & 1,064 \\
\hline
\end{tabular}




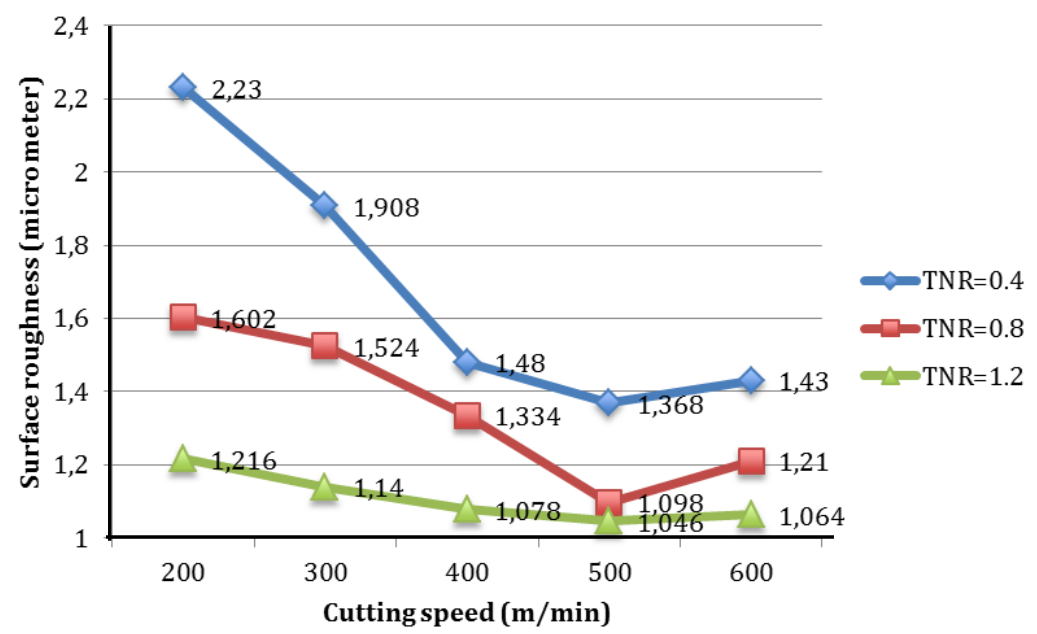

Gambar 7. Grafik nilai kekasaran permukaan variasi kecepatan pemotongan dan Tool nose radius

Dari Gambar 7 diketahui bahwa perbedaan tool nose radius dan perbedaan kecepatan potong sangat berpengaruh terhadap kekasaran permukaan benda kerja. Kenaikan kekasaran permukaan berlangsung secara linear dengan kenaikan cutting speed dan kenaikan tool nose radius.

Peningkatan kecepatan pemotongan menyebabkan gerakan pahat menjadi lebih cepat melakukan gesekan pada permukaan logam. Sehingga sudut ujung mata pahat (TNR) bergerak menusuk dan menyayat benda kerja kemudian melakukan gerakan pemotongan logam. Ketika serpihan yang dihasilkan terbentuk akibat gaya yang terjadi pada proses pemotongan tersebut secara kontinu akan menyebabkan besarnya sudut shear pada bidang kontak mata pahat dan serpihan, dan pada akhirnya akan putus sehingga serpihan terbentuk menjadi lebih pendek. Gaya dorong sudut mata pahat yang kuat menghilangkan sebagian serpihan pada bidang kontak mata pahat dan benda kerja, dan menimbulkan bekas goresan pada permukaan benda kerja sebesar sudut ujung mata pahat. Hal ini yang menyebabkan terjadinya goresan pada permukaan benda kerja dan menimbulkan nilai kekasaran permukaan.

Tabel 2. Persentase penurunan nilai kekasaran permukaan variasi Kecepatan Pemotongan

\begin{tabular}{|c|c|c|c|c|c|c|c|c|c|c|}
\hline \multirow{3}{*}{$\begin{array}{l}\text { TNR } \\
(\mathrm{mm})\end{array}$} & \multicolumn{10}{|c|}{ Kecepatan Potong (mm/min) } \\
\hline & 200 & $\mathrm{Ra}(\%)$ & 300 & $\mathrm{Ra}(\%)$ & 400 & $\mathrm{Ra}(\%)$ & 500 & $\operatorname{Ra}(\%)$ & 600 & $\mathrm{Ra}(\%)$ \\
\hline & \multicolumn{10}{|c|}{ Surface Roughness } \\
\hline 0,4 & 2,33 & \multirow{2}{*}{28,16} & 1,908 & \multirow{2}{*}{20,13} & 1,48 & \multirow{2}{*}{9,86} & 1,368 & \multirow{2}{*}{19,74} & 1,43 & \multirow{2}{*}{15,38} \\
\hline \multirow{2}{*}{0,8} & \multirow{2}{*}{1602} & & \multirow{2}{*}{1,524} & & \multirow{2}{*}{1,334} & & \multirow{2}{*}{1,098} & & \multirow{2}{*}{1,21} & \\
\hline & & 24,09 & & 25,2 & & 19,19 & & 4,74 & & 12,07 \\
\hline \multicolumn{2}{|c|}{ Rata-rata } & 26,13 & & 22,66 & & 14,53 & & 12,24 & & 13,73 \\
\hline
\end{tabular}

Tabel 2 menunjukkan penurunan persentase nilai kekasaran permukaan dari lima jenis kecepatan potong yang berbeda.

Dari Gambar 8 dapat dilihat bahwa grafik cenderung menurun. Dapat disimpulkan semakin besar kecepatan potong, maka penurunan kekasaran permukaan terhadap tool nose radius semakin kecil. Pada setiap pembesaran sudut ujung mata pahat dengan kelipatan 0,4 dihasilkan rata-rata penurunan harga kekasaran permukaan pada $V_{c}=200 \mathrm{~m} / \mathrm{min}$ adalah sebesar 26,3\%, sedangkan pada $\mathrm{Vc}_{\mathrm{c}}=300 \mathrm{~m} / \mathrm{min}$ adalah 22,66\%, Vc $=400 \mathrm{~m} / \mathrm{min}$ adalah $14,53 \%$, Vc $=500 \mathrm{~m} / \mathrm{min}$ adalah $12,24 \%$, dan yang terakhir $\mathrm{Vc}=600 \mathrm{~m} / \mathrm{min}$ adalah 13,73\%, memiliki arti untuk penurunan kekasaran permukaan terhadap sudut ujung mata pahat jika semakin besar kecepatan pemotongan maka persentase penurunan kekasaran permukaannya semakin kecil. 


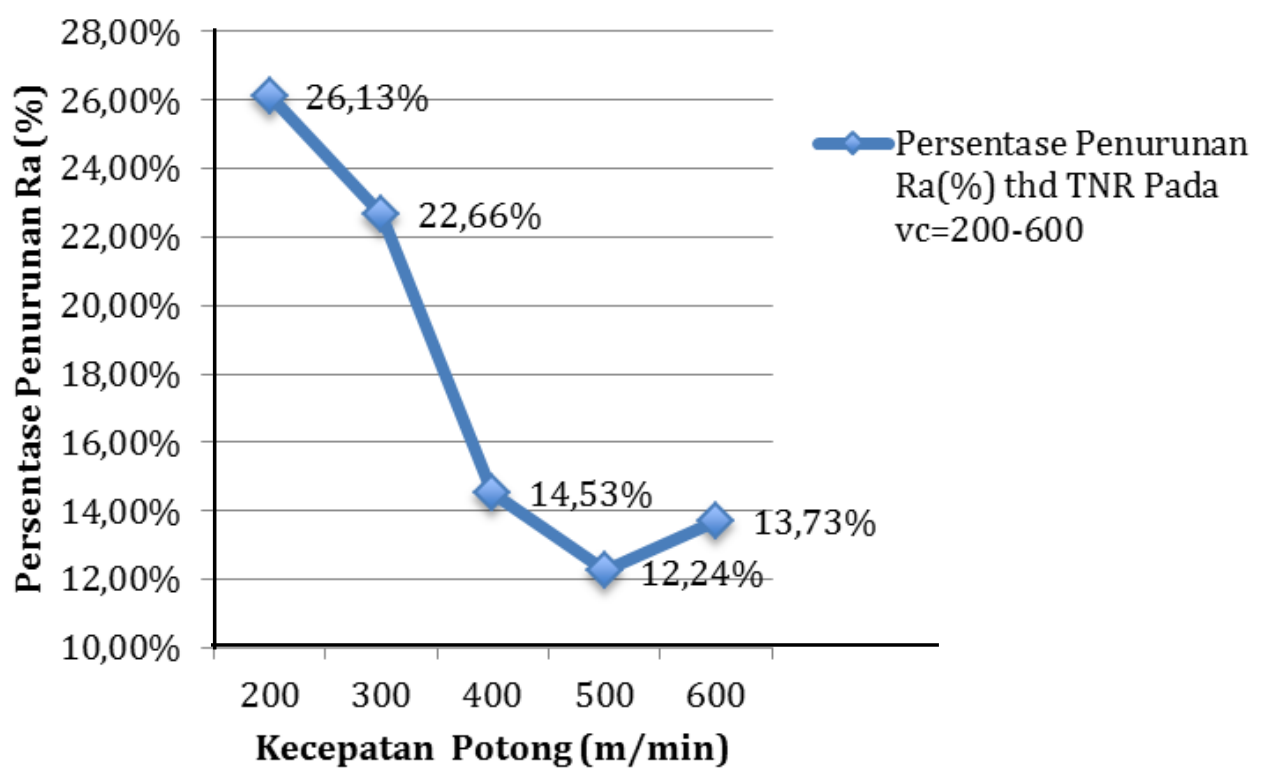

Gambar 8. Persentase penurunan kekasaran permukaan variasi kecepatan potong

Dari Gambar 8 dapat dilihat bahwa grafik cenderung menurun. Dapat disimpulkan semakin besar kecepatan potong, maka penurunan kekasaran permukaan terhadap tool nose radius semakin kecil. Pada setiap pembesaran sudut ujung mata pahat dengan kelipatan 0,4 dihasilkan rata-rata penurunan harga kekasaran permukaan pada $V_{c}=200 \mathrm{~m} / \mathrm{min}$ adalah sebesar 26,3\%, sedangkan pada $\mathrm{Vc}_{\mathrm{c}}=300 \mathrm{~m} / \mathrm{min}$ adalah 22,66\%, $\mathrm{Vc}_{\mathrm{c}}=400 \mathrm{~m} / \mathrm{min}$ adalah $14,53 \%$, Vc $=500 \mathrm{~m} / \mathrm{min}$ adalah $12,24 \%$, dan yang terakhir $\mathrm{Vc}=600 \mathrm{~m} / \mathrm{min}$ adalah 13,73\%, memiliki arti untuk penurunan kekasaran permukaan terhadap sudut ujung mata pahat jika semakin besar kecepatan pemotongan maka persentase penurunan kekasaran permukaannya semakin kecil.

Tabel 3. Persentase penurunan nilai kekasaran permukaan variasi Tool Nose Radius

\begin{tabular}{|c|c|c|c|c|c|c|}
\hline \multirow{3}{*}{$\begin{array}{l}\text { Kecepatan } \\
\text { Potong } \\
(\mathrm{mm} / \mathrm{min})\end{array}$} & \multicolumn{6}{|c|}{ Tool Nose Radius (mm) } \\
\hline & 0,4 & $\mathrm{Ra}(\%)$ & 0,8 & $\mathrm{Ra}(\%)$ & 1,2 & $\mathrm{Ra}(\%)$ \\
\hline & \multicolumn{6}{|c|}{ Surface Roughness } \\
\hline 200 & 2,23 & \multirow{2}{*}{14,44} & 1,602 & \multirow{2}{*}{4,87} & 1,22 & \multirow{2}{*}{6,25} \\
\hline 300 & 1,908 & & 1,524 & & 1,14 & \\
\hline \multirow{2}{*}{400} & \multirow{2}{*}{1,48} & 22,43 & \multirow{2}{*}{1,334} & 12,47 & & 5,44 \\
\hline & & \multirow{2}{*}{7,57} & & \multirow{2}{*}{17,69} & 1,070 & \multirow{2}{*}{2,97} \\
\hline 500 & 1,368 & & 1,098 & & 1,046 & \\
\hline 600 & 1,43 & $-4,53$ & 1,21 & $-10,20$ & 1,064 & $-1,72$ \\
\hline Rata-rata & & 9,98 & & 6,21 & & 3,23 \\
\hline
\end{tabular}

Tabel 3 menunjukan penurunan rata-rata nilai kekasaran permukaan dari tiga variasi tool nose radius.

Dari Gambar 9 dapat dilihat bahwa grafik cenderung menurun. Dapat disimpulkan semakin besar tool nose radius, maka penurunan kekasaran permukaan terhadap kecepatan potong semakin kecil. Pada setiap kenaikan kecepatan pemotongan dengan kelipatan $100 \mathrm{~m} / \mathrm{min}$ maka angka penurunan kekasaran permukaan dengan TNR $=0,4$ adalah sebesar 9,98\%, TNR $=0,8$ adalah sebesar 6,21\% , dan yang terakhir untuk TNR 1,2 adalah 3,23\%. 


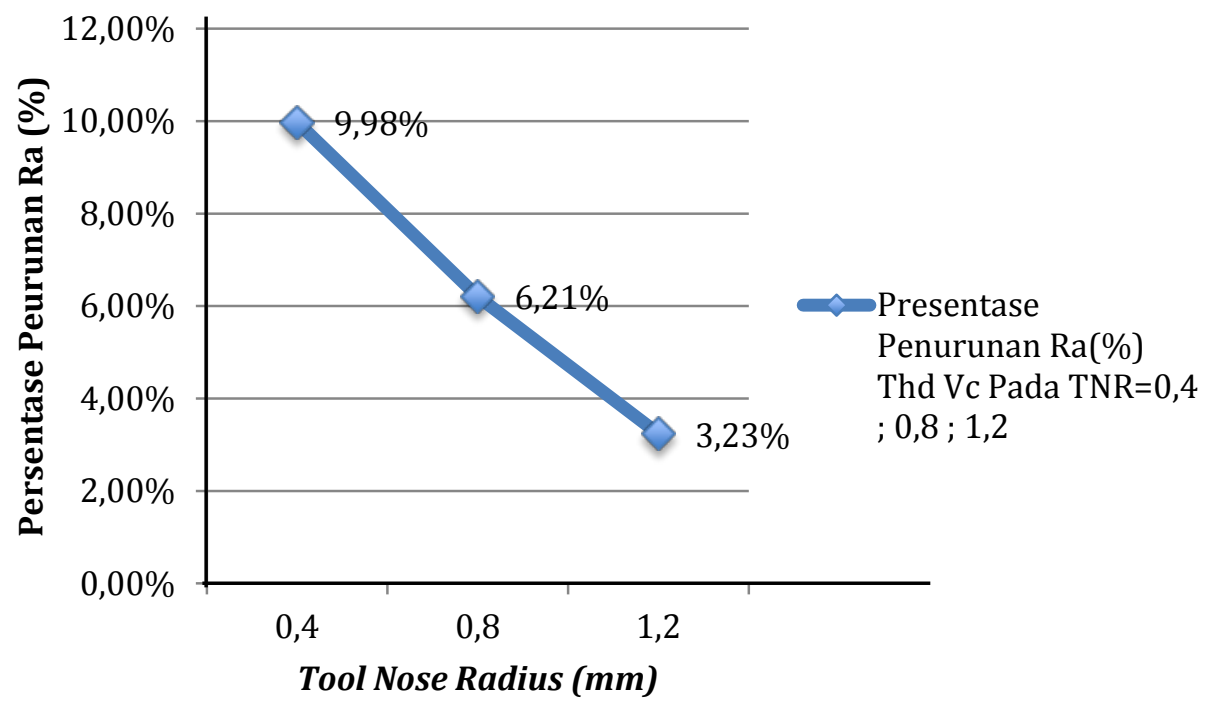

Gambar 9. Persentase penurunan nilai kekasaran permukaan variasi tool nose radius

Dari penjelasan ini dapat diketahui bahwa penggunaan sudut ujung mata pahat yang lebih besar menghasilkan penurunan kekasaran permukaan rata-rata sebesar 6,47\%. sedangkan penurunan penggunaan kecepatan pemotongan menghasilkan penurunan kekasaran permukaan sebesar 17,8\%. Hal ini menunjukkan bahwa pengaruh peningkatan kecepatan pemotongan lebih tinggi terhadap penurunan kekasaran permukaan berbanding peningkatan penggunaan sudut ujung mata pahat. Dalam melakukan proses pemesinan, untuk menghasilkan kekasaran permukaan yang lebih halus hendaknya menggunakan kecepatan pemotongan yang lebih besar dari rekomendasi disampaikan pada katalog mata pahat potong, dan menggunakan sudut ujung mata pahat yang lebih besar.

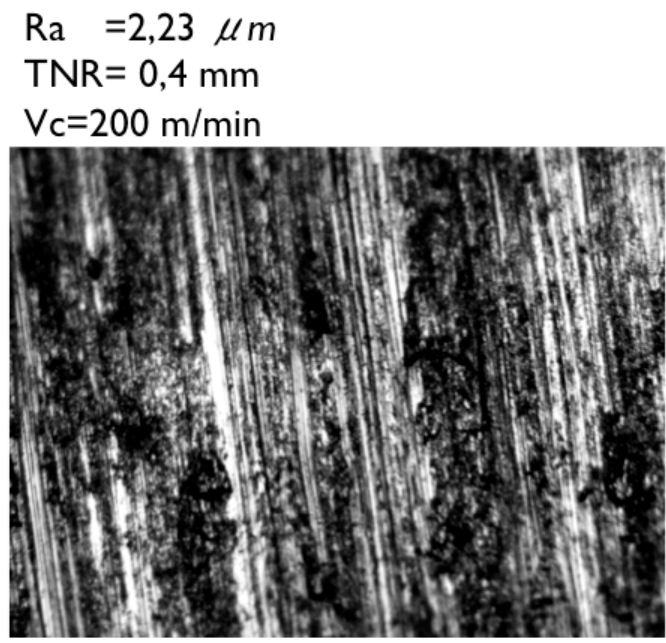

Pembesaran $100 x$

$$
\begin{aligned}
& \mathrm{Ra}=1,046 \mu \mathrm{m} \\
& T N R=1,2 \mathrm{~mm} \\
& V_{c}=500 \mathrm{~m} / \mathrm{min}
\end{aligned}
$$

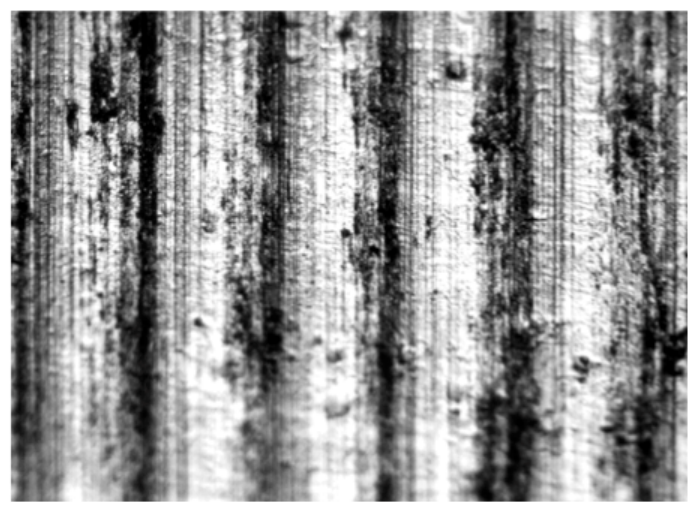

Pembesaran $100 x$

Gambar 10. Perbandingan topografi permukaan yang paling halus dan yang paling kasar

Pada Gambar 10 dapat dilihat variasi tool nose radius memiliki peran yang sangat penting terhadap kekasaran permukaan. besar tool nose radius dapat dilihat dari besar sayatan yang terjadi pada permukaan benda kerja. Besarnya jarak sayatan yang dihasilkan diperoleh dari penggunaan sudut ujung mata pahat yang lebih besar. Dari gambar diketahui bahwa garisan putih menunjukkan goresan yang terjadi pada permukaan benda kerja. Apabila nilai kekasaran permukaan semakin besar maka warna putih yang merupakan focus material akan menjadi semakin sedikit. Begitu juga sebaliknya jika warna putih pada gambar semakin banyak maka angka kekasaran permukaan pun 
akan semakin kecil. Sedangkan warna hitam menunjukkan bagian dalam yang tidak mampu diukur oleh stylus surface test.

\section{SIMPULAN}

Dari penelitian yang telah dilakukan maka dapat disimpulkan beberapa hal sebagai berikut: 1) Nilai kekasaran permukaan berbanding terbalik dengan kenaikan radius dari sudut ujung mata pahat (tool nose radius). Semakin besar sudut ujung mata pahat, maka semakin kecil nilai kekasaran permukaan yang dihasilkan. Hal serupa juga terjadi pada kecepatan pemotongan yang berbanding terbalik dengan kekasaran permukaan. 2) Semakin besar kecepatan pemotongan, maka semakin kecil nilai kekasaran permukaan. 3) Nilai kekasaran permukaan yang paling rendah adalah 1,046 $\mu \mathrm{m}$ dengan Kecepatan pemotongan $500 \mathrm{~m} / \mathrm{min}$ dan sudut ujung mata pahat 1,2 mm. 4) Penurunan kekasaran permukaan diperoleh lebih tinggi dipengaruhi oleh kecepatan potong berbanding variasi sudut ujung mata pahat, dimana nilai kekasaran permukaan variasi kecepatan pemotongan sebesar $17,8 \%$, dan pengaruh sudut ujung mata pahat sebesar 6,47\%.

\section{UCAPAN TERIMA KASIH}

Peneliti mengucapkan terima kasih kepada Direktorat Penelitian dan Pengabdian Kepada Masyarakat Universitas Tarumanagara yang telah membiayai penelitian ini Periode II tahun 2016.

\section{DAFTAR PUSTAKA}

[1]. Rochim, Taufiq, 1993, Teori \& Teknologi Proses Pemesinan, HEDS-JICA Bandung Indonesia.

[2]. Stephen, D.A., Agapiou, J.S., 1997, Metal Cutting Theory and Practice, Marcel Dekker.Inc. 270 Madison Avenue New York 10016.

[3]. Avallone, E.A., Baumeister, T., 1997, Standard Handbook for Mechanical Engineer, Mc.Graw Hills New York.

[4]. Munadi, Sudji, 1980, ”Dasar-Dasar Metrologi Industri”, Jakarta: Proyek Pengembangan Lembaga Pendidikan Tenaga Kependidikan

[5]. Richard, Horvate, Agota Dregelyi-Kiss, 2015, Analysis of Surface Roughness of Alumina Alloy Fine Turned: United Phenomenological Models and Multi-Performance Optimization, Measurement 2015.01.013.

[6]. Kalpakjian, S. Dan Steven, R. S., 2001, Manufacturing Processes for Engineering Materials, New Jersey: Prentice Hall. 